Р. О. Довжаниця

Житомирський науково-дослідний експертно-

криміналістичний иентр МВС Украӥни

R. Dovzhanytsia

Zhytomyr Scientific Research Forensic Center, MIA of Ukraine

\title{
ДОСЛІДЖЕННЯ РУКОПИСІВ ПСИХІЧНО ХВОРИХ ОСІБ ПІД ЧАС СУДОВОЇ ПОЧЕРКОЗНАВЧОЇ ЕКСПЕРТИЗИ
}

\author{
FRESEARCH OF MENTALLY ILL PERSONS’ MANUSCRIPTS \\ DURING FORENSIC HANDWRITING EXAMINATION
}

\begin{abstract}
Мета статті - з'ясувати можливості виявлення комплексу окремих діагностичних ознак у рукописах психічно хворих осіб, їх виокремлення та використання під час судової почеркознавчої експертизи для визначення конкретного «збивального» чинника та позитивного вирішення поставленого експертного завдання (завдань). У процесі розгляду теми окреслено можливості діагностичних досліджень щодо визначення загальнофізичних, психологічних, професійних якостей авторів рукописів. Сформовано рекомендації із застосування комплексного підходу до використання отриманих результатів дослідження та взяття їх за основу обгрунтованого експертного висновку. Запропоновано результати експериментальних досліджень рукописів осіб, хворих на шизофренію. Узагальнено досвід судового почеркознавства. Наголошено на поетапному, всебічному та об'єктивному підході до розв'язання поставленого перед експертом завдання. Достовірність отриманих результатів і висновків забезпечено такою системою методів наукового пізнання, зокрема: формальної логіки (аналіз, синтез, індукція, дедукція, аналогія, абстрагування) - для детального з'ясування змісту розглядуваних питань, теоретичний - для аналізу наукової та навчально-методичної літератури, метод системного аналізу - у контексті розв'язання поставленого експертного завдання.

Ключові слова: почерковий об’єкт; «збивальний» чинник; судова почеркознавча експертиза; діагностичні дослідження; ідентифікаційні ознаки; психічні розлади; рукописи; експертний висновок.
\end{abstract}

Цель статьи - раскрыть возможности выявления комплекса отдельных диагностических признаков в рукописях психически больных лиц, их различения и использования во время судебной почерковедческой экспертизы для определения конкретного «сбивающего» фактора и положительного решения поставленной экспертной задачи (задач). В процессе рассмотрения темы обозначены возможности диагностических исследований по определению общефизических, психологических, профессиональных качеств авторов рукописей. Сформированы рекомендации по применению комплексного подхода к использованию полученных результатов исследования, что должны лечь в основу обоснованного экспертного заключения. Предложены результаты экспериментальных исследований рукописей лиц, больных шизофренией. Обобщен опыт судебного почерковедения. Акцентировано внимание на поэтапном, всестороннем и объективном подходе к решению поставленной перед экспертом задачи. Достоверность полученных результатов и выводов, обеспечена системой методов научного познания, в частности: формальной логики (анализ, синтез, индукция, дедукция, аналогия, абстрагирование) - для детального рассмотрения содержания исследуемых вопросов, теоретический - для анализа научной и учебно-методической литературы, метод системного анализа - в контексте решения поставленной экспертной задачи.

Ключевые слова: почерковой объект; «сбивающий» фактор; судебная почерковедческая экспертиза; диагностические исследования; идентификационные признаки; психические расстройства; рукописи; экспертное заключение. 
The purpose of the article is to find out the possibilities of identifying a range of individual diagnostic features in the manuscripts of mentally ill persons, separation and use of these features during handwriting examination to determine a specific «distinctive» factor in order to solve the expert tasks. In the course of the research, the possibilities of diagnostic studies for determination of general physical, psychological and professional qualities of the manuscripts' authors were outlined. The author of the article formulated recommendations on the application of a comprehensive approach to the usage of the obtained research results and on how to provide substantiated expert opinion based on these results. The results of experimental studies of manuscripts of persons with schizophrenia are represented as well. The experience of forensic handwriting research is generalized. The author emphasizes on a gradual, comprehensive and objective approach of an expert in the set task solving. The research is provided by the following system of scientific methods: method of formal logic (analysis, synthesis, induction, deduction, analogy, abstraction) - for a detailed clarification of the considered issues content; theoretical method - for the analysis of scientific and methodological literature; method of systematic analysis - in the context of solving the set expert task.

Keywords: handwriting object; «distinctive» factor; forensic handwriting examination; diagnostic studies; identification characteristics; mental disorders; manuscripts; expert opinion.

Сьогодні в Україні, в умовах розвитку ринкових відносин суттєво зросла кількість майнових угод (договорів купівлі-продажу, ренти, дарування тощо), які укладають громадяни, а отже й проваджень у цивільних справах, кримінальних проваджень, які відкривають з приводу визнання зазначених угод недійсними, і відповідно судових почеркознавчих експертиз, що призначають у межах цих проваджень.

Основним завданням судового експерта, який досліджує рукопис, є отримання максимального обсягу відомостей, необхідних для досудового розслідування та розгляду справи в суді.

У судовому почеркознавстві спрямовують увагу на вивчення змісту ознак почерку як вираженню властивостей письмового-рухового функціонально-динамічного комплексу, їх психофізіологічної природи.

Відомо, що на почерк накладає відбиток багато чинників: вік автора рукопису, його здоров’я тощо. Значною мірою на почерк впливає спотворена психіка, на що зважають, навіть коли встановлюють діагноз. Відповідно непоодинокими є дослідження рукописів, які виконували особи з психічним захворюванням або з психічними відхиленнями.

За статистикою, в Україні загалом 1,2 млн людей (понад 3 \% населення) страждають на психічні розлади, і цей показник щороку зростає. Україна посідає перше місце в Європі за кількістю осіб із психічними розладами (рис. 1) (Institute for Health Metrics, 2016). А отже дослідження рукописів людей із психічними проблемами нині відповідає потребам експертної та судової практики і зумовлює свою актуальність.

Діагностичні дослідження рукописів людей, що мають проблеми 3 психікою, як і будь-які інші діагностичні дослідження, що становлять методологічну основу вирішення неідентифікаційних завдань, посідають важливе місце як у криміналістиці загалом, так і в судовій експертизі зокрема. Методику діагностичних досліджень слід розглядати як окремий метод наукового пізнання.

Проблеми, зокрема діагностичних досліджень рукописів, вивчали $Є$. Ф. Буринський (один із перших криміналістів, що почав розробляти основи судової почеркознавчої експертизи, Євгену Федоровичу належить й авторство терміна «почеркознавство»), а також Л. Ю. Ароцкер, М. Є. Бондар, Л. А. Вінберг, В. Г. Грузкова, А. А. Купріянова, В. В. Липовський, А. І. Манцвєтова, 3. С. Меленевська, Е. Б. Мельникова, І. М. Можар, В. Ф. Орлова, Є. Ю. Свобода, В. В. Томілін, М. В. Шванкова та ін.

Різні причини, помітили вчені-криміналісти, по-різному впливають на процес письма та властивості почерку. Властивість почерку реагувати на різні психофізіологічні чинники 
проявляється, коли зміни умов письма є такими значними, що успішне пристосування до них механізму письма неможливе. У результаті звичний автоматичний процес письма порушується, і в почерку відбуваються зміни, які не можна вважати варіаційними.

Зв'язок між психологічними властивостями виконавця рукопису та почерком вивчає графологія (психодіагностична методика, яка припускає дослідження психомоторного та підсвідомого підгрунтя графічних явищ, а також синтез цілісної картини досліджуваної особи; використовує понятійний апарат сучасної психологічної науки та корелює 3 наявними типологіями особистості), частково й психологія. Проте почеркознавство не має

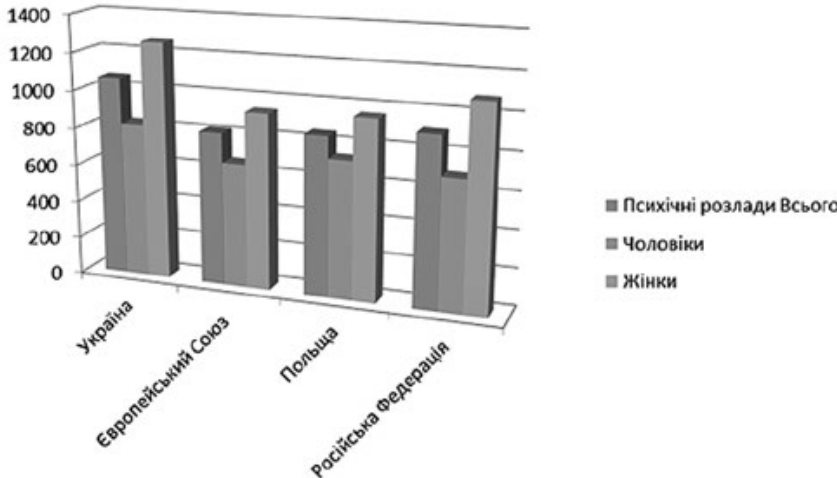

Рис. 1. Кількість людей із психічними розладами в Україні та країнах - членах Всесвітньої організації охорони здоров'я на 100000 осіб, 2015 р. (ураховано всі вікові групи) прямого зв'язку ні з психологією, ні з психіатрією і не передбачає виконання психодіагностичної роботи.

3 огляду на зазначене вчені-криміналісти та почеркознавці-практики працюють над встановленням за почерком загальнофізичних властивостей, віку, професійної належності, психологічного стану виконавців рукописів. Використовуючи доробок сучасних графологів, розв'язують завдання діагностичного (неідентифікаційного) характеру, зокрема зі встановлення факту незвичайного виконання рукопису. За результатами аналізу почерку вивчають внутрішній стан автора рукопису, у тому числі пов'язаний із віковими змінами організму, переохолодженням, перегрівом, алкогольним сп'янінням, утратою зору, фізичною втомою тощо, можуть з'ясувати та дослідити спосіб свідомої зміни почерку, мету і завдання, що ставив перед собою автор рукопису, навмисно маскуючи свій почерк, тощо.

Водночас одностайності криміналістів із цього питання бракує. У літературних джерелах висловлюються суперечливі думки про таку кореляційну залежність між почерком і окресленими вище властивостями людини. А отже як для теорії, так і для практики судових почеркознавчих експертиз на часі - створення нових методик неідентифікаційних досліджень почерку, що дасть змогу отримувати необхідну інформацію, звужуючи тим самим коло пошуку ймовірних виконавців тексту.

Мета статті - з'ясувати можливості виявлення комплексу окремих діагностичних ознак у рукописах психічно хворих осіб, їх виокремлення та використання під час судової почеркознавчої експертизи для визначення конкретного виду «збивального» чинника та позитивного вирішення поставленого експертного завдання (завдань).

Встановлення конкретного «збивального» чинника в рукописі може бути як самостійним діагностичним завданням, сформульованим ініціатором, який призначив експертизу, так і проміжним (підзавданням), яке експерт визначає сам у процесі дослідження.

Важлива умова вирішення будь-якого діагностичного завдання - наявність оригіналу досліджуваного документа. Разом із почерковим об'єктом підставою для поділу діагностичних завдань $€$ також порівняльний матеріал: зразки почерку певної особи. 
Тобто діагностичні завдання можуть вирішуватися за наявності досліджуваного об'єкта або досліджуваного об'єкта і порівняльного матеріалу (повний компонентний склад), формуючи тим самим незалежно від цільової настанови та особливостей почеркового об’єкта дві групи таких завдань.

Умови вирішення діагностичних завдань передбачають і наявність відомостей про ймовірного виконавця (вік, стан здоров'я тощо), обставини, пов'язані з виконанням досліджуваного об'єкта, а також наявність тих чи інших «збивальних» чинників у момент виконання почеркової реалізації, становлячи підстави поділу діагностичних завдань.

Криміналістична діагностика тісно пов’язана з криміналістичною ідентифікацією. У межах ідентифікаційного процесу вирішують і діагностичні завдання. Тобто на практиці діагностика та ідентифікація є окремими частинами цілого, у нашому випадку єдиної мети. Так, під час ідентифікації особи за почерком може виникнути потреба в діагностиці їі статі, віку, стану під час написання документа. Різняться вони предметом пізнання та зв'язками об'єктів із подією кримінального правопорушення.

Почерк як функціональне утворення, що має пристосувальне значення, відображає властивості високоорганізованих динамічних систем: високу сталість і водночас рухливість, надійність, можливість компенсаторних змін тощо. Разом із тим зміна умов і мети написання рукопису, інші чинники трансформують функціональну програму рухів.

Динамічність почерку проявляється:

у статистичній стереотипності рухів особи, яка пише, що реалізують зорово-руховий образ букв, їх сполучень, слів і рукопису в цілому;

варіаційності ознак почерку й почерку загалом;

вибірковій мінливості почерку під впливом «збивальних» чинників.

Отже, письмо $€$ носієм не лише ідентифікаційної інформації про особу, яка пише. У ньому відображаються також іiї психофізіологічні властивості та умови, за яких відбувається процес письма. Як продукт вищої нервової діяльності людини письмо чутливо реагує на зовнішні та внутрішні зміни. Здатність почерку відбивати різні психофізіологічні чинники створює передумови для отримання в межах діагностичних досліджень відомостей про внутрішній стан виконавця та зовнішню обстановку під час написання рукопису (Arotcker, Vul, Brodskaia, Gordeeva, Gruzkova, \& Mozhar, 1972).

Труднощі, пов’язані зі встановленням обставин виконання рукопису за результатами неідентифікаційних експертних досліджень, зумовлені насамперед тим, що під впливом на виконавця рукопису різних чинників ознаки почерку, які відображаються в ньому, можуть змінюватися однотипно, і зміни координації рухів під час письма - наслідок цього. Крім того, не можна достатньо чітко і точно диференціювати ознаки почерку в рукописах, написаних у різних умовах і в різних станах. Відповідно, вирішуючи неідентифікаційні завдання, судовим експертам доводиться вивчати характер зміни почерку, зважаючи на вплив безлічі умов (Melenevska, Svoboda, \& Shabotenko, 2007). Тому вони здебільшого вирішують завдання неідентифікаційного характеру тільки в імовірній формі. Іноді вдається встановити лише сам факт виконання рукопису в незвичних умовах без конкретного їх визначення.

До того ж під час діагностичних досліджень рукописів авторів з психологічними відхиленнями бракує чітко сформованої системи ознак почерку, властивих конкретному виду захворювання, зафіксовані лише певні спостереження (Arotcker, Vul, Brodskaia, Gordeeva, Gruzkova, \& Mozhar, 1972; Arinushkin, Vinberg, \& Shliakhov, 1975; Melenevska, \& Shpakovych, 2015, Otsinochna diialnist). 
Так, у рукописах людей, хворих на шизофренію, спостерігається велика кількість підкреслень і розділових знаків, вигадливе виконання прописних букв і заключних штрихів, розміщення тексту колонкою або за діагоналлю, пропускання букв і слів, нерівномірність натиску, закреслювання, виправлення, інколи атаксія.

Параноїки використовують у рукописах символічні знаки замість букв, велику кількість знаків наголосу, підкреслення, викривлення та утворення нових слів, повторення фраз, ілюстрації кресленнями.

Для рукопису епілептиків характерні зловживання розділовими знаками (крапки після кожного слова) і прописними буквами, рівномірний натиск, малий розгін, атаксія в окремих випадках.

До порушення рухових навичок, а отже й до зміни ознак почерку призводять стійкі остаточні явища (порушення рухових, чуттєвих та інших функцій) крововиливів або інфарктів мозку. У цих випадках, засвідчують результати експериментів, проведених на базі Київського НДІСЕ та Інституту геронтології НАМН України, погіршується координація рухів, уповільнюється темп письма, збільшується ступінь зв'язаності, нахил літер стає нечіткий, наявні тенденції до підсилення натиску і послаблення його диференціації, спостерігається зміна ознак просторової орієнтації, а також деяких окремих ознак (Melenevska, \& Shpakovych, 2015, Otsinochna diialnist, s. 56).

У хворих на паркінсонізм спостерігається деградація письмової навички, яка проявляється в погіршенні координації рухів, уповільненні темпу письма, збільшенні тремтіння писального приладу, зменшенні чіткості букв і появі виправлень їх елементів, збільшенні ступеня зв'язності (рис. 2).

У Житомирському НДЕКЦ МВС спільно з фахівцями Житомирської обласної психіатричної лікарні були проведені експериментальні дослідження рукописів осіб, хворих на шизофренію. Для дослідження відбирали рукописи та малюнки (зображення) 20 осіб різних вікових груп на ранніх етапах захворювання (період хвороби від п'яти до десяти років).

Рукописи виконані хворими, сидячи за столом, на чистих і пожовклих аркушах паперу формату A4, A5 у довільній формі на вільну тематику.

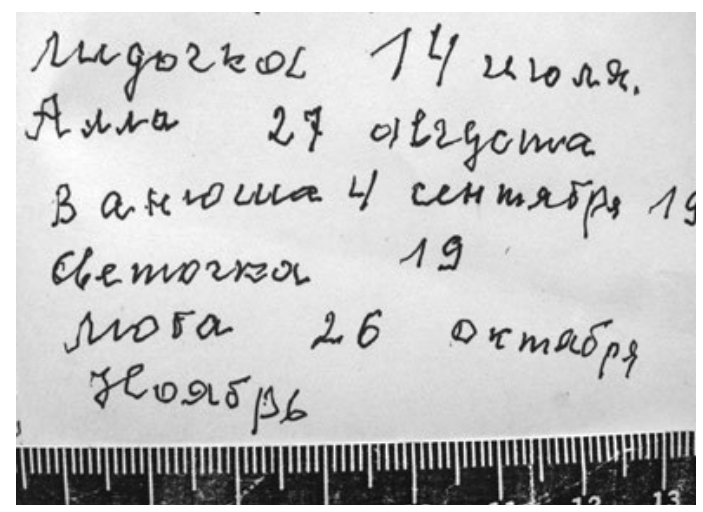

Рис. 2. Фрагмент рукописного тексту 3 деградацією письмово-рухової навички хворого на паркінсонізм

Обсяг отриманих для дослідження рукописів становив не менше 0,25 сторінки (приблизно 40-60 письмових знаків), що найчастіше трапляється в експертній практиці. Характерними ознаками рукописів були:

рукописний текст (почеркознавче дослідження)

невмотивовані закреслення літер, слів і речень;

повтори окремих елементів літер;

виконання в тексті найрізноманітніших піктограм або ідеограм, схематичних рисунків, фігур або знаків (рис. 3);

відсутність у реченнях завершальних словосполучень або слів, у словах - останніх складів або літер, у письмових знаках - завершальних елементів або їх частин; 
незвичайне виконання великих літер і розділових знаків;

незвичайна конфігурація розділових знаків;

«вичурність» конфігураційних характеристик письмових знаків;

незвичайне розміщення рукопису на аркуші паперу або самостійних фрагментів тексту (рис. 4);

наявність ознак атаксії в окремих фрагментах рукопису;

\section{рукописний текст (авторознавче дослідження)}

втрата єдності змісту рукопису;

безсистемні пропускання слів або літер;

здебільшого нижчий за середній та низький ступінь розвитку граматичних і лексичних навичок письма;

спосіб акцентування уваги у вигляді закреслювання слів, речень - ступінь розвитку стилістичних навичок письма.

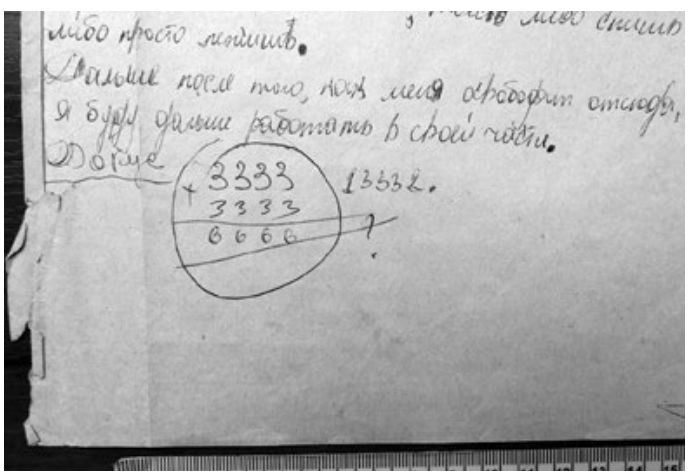

Рис. 3. Фрагмент рукописного тексту хворого на шизофренію зі схематичними символами, фігурами та знаками

Малюнкам (зображенням) притаманнi:

символізація почуттів, особистих переживань, страху (рис. 5);

відображення різноманітних настроїв і моторошних елементів;

відображення особистих галюцинацій. барвлені.

Крім того, зображення негативно за-

Аналізуючи ці ознаки, нескладно дійти висновків щодо необхідності їх упорядкування та комплексного узагальнен-

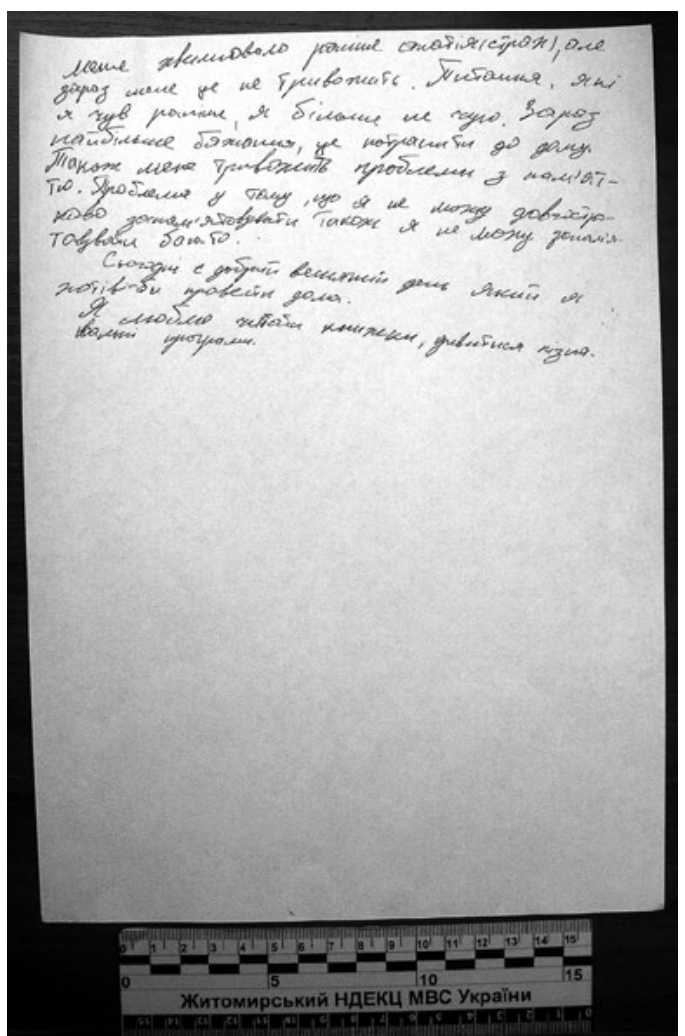

Рис. 4. Незвичайне розміщення на аркуші паперу рукописного тексту хворого на шизофренію ня, аби як учені-криміналісти, так і судові експерти, що проводять судові почеркознавчі експертизи, однозначно й об'єктивно могли їх тлумачити.

Важливу роль діагностичного (неідентифікаційного) дослідження та його вплив на результати судового розгляду справи засвідчує приклад з експертної практики.

У 2015 р. однією зі сторін цивільного процесу було заявлено клопотання про призначення у справі судової почеркознавчої експертизи на предмет дослідження підпису та 


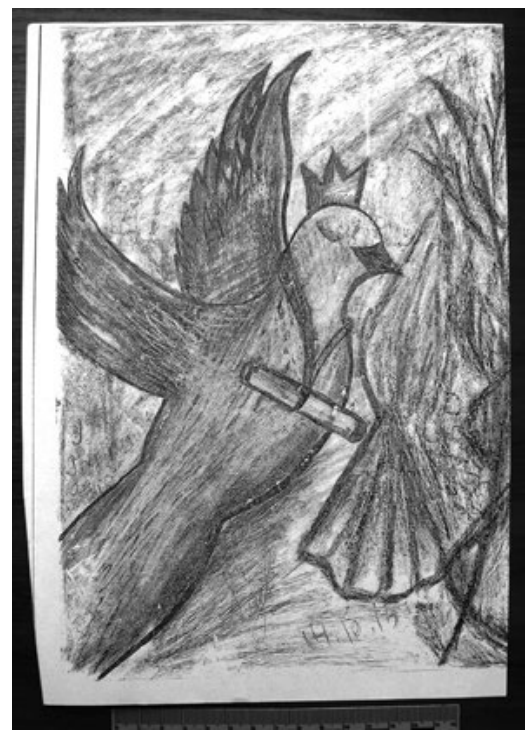

Рис. 5. Символізація почуттів, особистих переживань, страху в зображенні хворого на шизофренію

рукописного тексту Л. у спірному нотаріально завіреному заповіті щодо визнання його недійсним.

На експертизу були надані оригінал досліджуваного документа, журнал реєстрації нотаріальних дій і достовірні вільні зразки рукописів Л., виконані нею в різні часи. У матеріалах справи згадувалося також про лікувальні заклади і те, що вона пройшла курс лікування.

Під час експертного дослідження судовий експерт встановив розбіжності більшості загальних та окремих ознак письма в досліджуваному документі та в зразках рукописів Л.

Крім того, в окремих зразках рукописів Л., виконаних нею в період часу, близького до часу написання досліджуваного документа, виявлено незвичності виконання письма у вигляді природного «збивального» чинника, не пов'язаного з навмисною зміною нею почерку, яких не було в досліджуваному документі.

В експертному висновку судовий експерт разом із розбіжними ознаками (етап установлення відсутності тотожності) проілюстрував та виокремив комплекс діагностичних ознак у наданих зразках рукописів, які згодом були покладені в основу категоричного негативного висновку щодо виконання рукопису в спірному заповіті особою, від імені якої вони значилися. Виявлений при цьому комплекс діагностичних ознак був оцінений (зважаючи на вікові зміни) як постійний і такий, що впливав на виконання зразків рукописів Л. через хворобливий стан (захворювання Паркінсона).

Пізніше на судовому засіданні документально підтверджено факт наявності в померлої Л. встановленого лікарями діагнозу паркінсонізму, який раніше не відображався в матеріалах справи, попри заявлені клопотання експерта.

Висновки. Завдяки поетапному, всебічному та об’єктивному підходу до розв’язання поставленого експертного завдання виявлений комплекс діагностичних ознак у сукупності з допоміжними фактами, отриманими процесуальним шляхом, дав змогу встановити істину у справі та довести нелегітимність досліджуваного документа.

Проте на практиці трапляється, що у висновках судових експертів за результатами судових почеркознавчих експертиз бракує вказівок на об’єктивні підстави оцінки, не зазначено вихідних даних, використаних експертом для оцінки ознак почерку, не проілюстровано діагностичних ознак у разі неідентифікаційних експертних досліджень, при цьому часто послуговуються шаблонними формулюваннями, які не виражають або частково виражають об’єктивні підстави оцінки експертом ознак почерку.

Подоланню окреслених хиб великою мірою сприятиме дотримання науково-практичних викладок, які знайшли відображення в таких проміжних висновках, сформульованих на підставі аналізу накопиченого досвіду експертної практики, літературних, у тому числі наукових, джерел із проблематики судового почеркознавства (Melenevska, \& Shpakovych, 2015, Sudove pocherkoznavstvo; Polevoi, 1989):

процес письма являє собою психофізіологічний акт, що виникає за певного співвідношення нейрофізіологічного та психічного стану, поведінковий прояв, в основі якого 
лежить психофізіологічна динаміка. Він визначається умовно-рефлекторною системою рухів, які складаються з автоматичних (підсвідомих) і свідомих компонентів;

поєднання методологічних підходів класичного криміналістичного почеркознавства та графології $€$ логічним і виправданим кроком подальшого розвитку мовознавства загалом і визначення комплексу психологічних рис особистості в почерковому матеріалі зокрема;

із ключових умов вирішення завдання за повного компонентного складу - надання судовому експерту достатньої кількості якісного порівняльного матеріалу, у тому числі електрофотокопій задовільної та високої якості, у яких (залежно від якості та ступеня прояву ідентифікаційних і діагностичних ознак) можуть спостерігатися ознаки порушення координації рухів першої та другої групи, а також порушення просторової орієнтації - найсуттєвіші ознаки для діагностування впливу на процес письма «збивальних» чинників. Проте електрофотокопії доцільно поєднувати з оригіналами цих документів;

виокремлення комплексу діагностичних ознак у сукупності з обставинами справи або документально підтвердженими фактами особливостей здоров'я виконавця досліджуваного рукопису дасть змогу експертам, які виконують почеркознавчу експертизу, висунути версію про можливу наявність у нього певного захворювання чи тимчасовий характер дії «збивальних» факторів, що сприятиме правильному оцінюванню встановлених під час дослідження ознак почерку;

при вирішенні діагностичних завдань висновок експерта, незалежно від характеру висновків (ступеня їх визначеності), обов'язково має супроводжуватися ілюстративним матеріалом (фотознімками) та розміткою, що не тільки забезпечить наочність і підвищить їх переконливість, а й полегшить перевірку достовірності оціночних суджень судового експерта;

накопичення ілюстративного матеріалу та використання методу експертних (спеціалізованих) оцінок - об’єктивна передумова складання повноцінних узагальнень експертної практики, що набуває особливого значення для вирішення проблемних питань та подальшого розвитку почеркознавства і вдосконалення практики виконання діагностичних експертиз;

використання в зазначеному виді досліджень математичних (геометричних) методів, зокрема графічних ідентифікаційних алгоритмів (АГІ), і ліцензійних програмних продуктів уможливлює діагностичні та ідентифікаційні дослідження в єдиному процесі, що зручно й доступно, гарантуючи досягнення науково обгрунтованого об'єктивного результату.

\section{References}

Arinushkin, G. P., Vinberg, A. I., \& Shliakhov, A. R. (1975). Naznachenie i proizvodstvo kriminalisticheskih eksperti. M.: Iurid. lit. $295 \mathrm{~s}$.

Arotcker, L. E., Vul, S. M., Brodskaia, A. B., Gordeeva, G. N., Gruzkova, V. G., \& Mozhar, I. M. (1972). Neidentifikazionnye issledovaniia $v$ pocherkovedcheskoi ekspertize. Kiev: RIO MVD Ukrainy. 96 s.

Institute for Health Metrics and Evaluation (IHME): GBD Results Tool. Seattle: WA: IHME, University of Washington. (2016). Retrieved from http://ghdx.healthdata.org/gbd-results-tool.

Melenevska, Z. S., Svoboda, Ye. Yu., \& Shabotenko, A. I. (2007). Sudovo-pocherkoznavcha ekspertyza: navch.metod. posib. / za zah. red. I. P. Krasiuka. Kyiv: Ukr. tsentr dukhovn. kultury. 280 s.

Melenevska, Z. S., \& Shpakovych, N. H. (2015). Otsinochna diialnist eksperta-pocherkoznavtsia: navch.-metod. posib. Kyiv: DNDEKTs MVS Ukrainy. $107 \mathrm{s.}$ 
Melenevska, Z. S., \& Shpakovych, N. H. (2015). Sudove pocherkoznavstvo: problemy i perspektyvy rozvytku. Kryminalistychnyi visnyk. № 1 (23). S. 113-120.

Polevoi, N. S. (1989). Kriminalisticheskaia kibernetika. 2-e izd. M.: Izdatelstvo MGU. 328 s.

\section{Список використаних джерел}

Аринушкин, Г. П., Винберг, А. И., \& Шляхов, А. Р. (1975). Назначение и производство криминалистических экспертиз. М.: Юрид. лит. 295 с.

Ароцкер, Л. Е., Вул, С. М., Бродская, А. Б., Гордеева, Г. Н., Грузкова, В. Г., \& Можар, И. М. (1972). Неидентификационные исследования в почерковедческой экспертизе. Киев: РИО МВД Украины. 96 с.

Institute for Health Metrics and Evaluation (IHME): GBD Results Tool. Seattle: WA: IHME, University of Washington. (2016). Retrieved from http://ghdx.healthdata.org/gbd-results-tool.

Меленевська, 3. С., Свобода, Є. Ю., \& Шаботенко, А. I. (2007). Судово-почеркознавча експертиза: навч.-метод. посіб. / за заг. ред. І. П. Красюка. Київ: Укр. центр духовн. культури. 280 с.

Меленевська, 3. С., \& Шпакович, Н. Г. (2015). Оціночна діяльність експерта-почеркознавия: навч.-метод. посіб. Київ: ДНДЕКЦ МВС України. 107 с.

Меленевська, 3. С., \& Шпакович, Н. Г. (2015). Судове почеркознавство: проблеми і перспективи розвитку. Криміналістичний вісник. № 1 (23). С. 113-120.

Полевой, Н. С. (1989). Криминалистическая кибернетика. 2-е изд. М.: Издательство МГУ. 328 с. 